\title{
DETERMINAN PROFITABILITAS BANK UMUM SYARIAH DI INDONESIA DENGAN TINGKAT LIKUIDITAS SEBAGAI VARIABEL INTERVENING
}

\author{
Sasabila Tisat Anisa ${ }^{\bowtie}$, Saiful Anwar \\ Institut Agama Islam Negeri (IAIN) Salatiga, Indonesia \\ sasabilatisat@gmail.com, saifulanwarmieta@iainsalatiga.ac.id \\ https://doi.org/10.46367/jps.v2i2.346 \\ Received: May 08, 2021 Revised: Jul 12, 2021 Accepted: Jul 21, 2021 Published: Oct 14, 2021
}

\begin{abstract}
This research aims to analyze the effect of capital adequacy ratio (CAR), financing risk (NPF), and operational efficiency (BOPO) on profitability (ROA) with liquidity level $(F D R)$ as an intervening variable in Islamic commercial banks (ICB) in Indonesia in 2015 to 2019. The data used is secondary data in panel data, taken from the annual reports published by each ICB official website. Data analysis used multiple linear regression and path analysis. The results of this study found that CAR has a negative effect on ROA, NPF has a negative effect on ROA, BOPO has a negative effect on ROA, FDR has a positive effect on ROA, $C A R$ has a negative effect on FDR, NPF has a negative effect on FDR, BOPO has a positive effect on FDR liquidity. At the same time, FDR cannot be an intervening variable in the relationship of CAR, NPF, BOPO to ROA. This research provides insight for ICB in maintaining the value of $N P F$ and BOPO to increase the company's net profit.
\end{abstract}

Keywords: ROA, CAR, NPF, BOPO, FDR

\begin{abstract}
ABSTRAK
Penelitian ini bertujuan untuk menganalisis pengaruh rasio kecukupan modal $(C A R)$, risiko pembiayaan $(N P F)$ dan efisiensi operasional (BOPO) terhadap profitabilitas $(R O A)$ dengan tingkat likuiditas $(F D R)$ sebagai variabel intervening pada bank umum syariah (BUS) di Indonesia tahun 2015-2019. Data yang digunakan adalah data sekunder berbentuk data panel, diambil dari laporan tahunan yang dipublikasikan masing-masing website resmi BUS. Analisis data menggunakan regresi linear berganda dan analisis jalur. Hasil penelitian ini menemukan bahwa $C A R$ berpengaruh negatif terhadap $R O A, N P F$ berpengaruh negatif terhadap $R O A$, BOPO berpengaruh negatif terhadap ROA, FDR berpengaruh positif terhadap $R O A, C A R$ berpengaruh negatif terhadap $F D R, N P F$ berpengaruh negatif terhadap $F D R$, BOPO berpengaruh positif terhadap likuiditas $F D R$, sedangkan FDR tidak mampu menjadi variabel intervening pada hubungan $C A R, N P F$, BOPO terhadap ROA. Penelitian ini memberikan insight untuk BUS dalam menjaga nilai $N P F$ dan BOPO sehingga dapat meningkatkan laba bersih perusahaan.
\end{abstract}

Kata Kunci: ROA, $C A R, N P F, \mathrm{BOPO}, F D R$ 


\section{PENDAHULUAN}

Perbankan syariah memegang peranan penting dalam perekonomian yaitu sebagai lembaga intermediasi bagi seluruh sektor, baik sektor pemerintah, usaha maupun sektor individu atau rumah tangga. Selain itu, peran industri keuangan syariah harus ditingkatkan secara kontributif dan iklusif karena lembaga keuangan syariah merupakan salah satu alternatif sumber pembiayaan program pembangunan nasional untuk pemerataan kesejahteraan masyarakat. Melihat bahwa perekonomian domestik maupun global saat ini juga mengalami kemerosotan dan kondisi yang tidak stabil akibat pandemi covid-19, sehingga sangat penting untuk meningkatkan ketahanan industri keuangan syariah terutama perbankan syariah dalam menghadapi risiko-risiko tersebut. Industri keuangan syariah harus selalu dikembangkan guna menjaga maslahah antar umat muslim untuk kehidupan dunia dan akhirat. Perbankan syariah harus selalu menjaga kinerjanya dengan baik, karena bank memegang kedudukan penting dalam perekonomian, sebagai lembaga intermediasi dari seluruh sektor baik individu atau rumah tangga, usaha maupun pemerintahan, sehingga stabilitas sistem keuangan tetap terjaga (Pardede and Pangestuti 2016).

Seluruh kinerja dari perbankan dapat dilihat melalui nilai profitabilitasnya. Kondisi suatu perusahaan dimasa depan dapat dilihat dan diprediksi melalui kinerja keuangannya, hal tersebut sangat penting untuk mengetahui keberlangsungan serta stabilitas suatu bisnis baik dari pihak internal maupun pihak eksternal sebagai pertimbangan dalam mengambil sebuah keputusan. Baik buruknya kinerja keuangan tersebut dapat dianalisis menggunakan rasio keuangan yang berada di laporan keuangan perusahaan ditinjau melalui neraca dan laporan laba rugi (Sanjaya and Rizky 2018). Rasio tersebut menjadi urgensi bagi perusahaan karena $R O A$ dipakai sebagai alat untuk mengukur efektifitas operasional perusahaan ketika mengelola aset untuk mendapatkan laba bersih (Pangestika and Musdholifah 2018). Alasan mengapa ROA dipilih menjadi rasio profitabilitas karena laba bersih atau net income adalah tolok ukur utama keberhasilan sebuah perusahaan. ROA bisa mengukur bagaimana perusahaan mendapatkan keuntungan dengan mengelola kekayaan yang sudah disesuaikan dengan biaya untuk pendanaan aset tersebut (Pardede and Pangestuti 2016). Selain itu nilai $R O A$ di tahun 2015-2019 mengalami nilai yang masih fluktuatif dan belum stabil (OJK 2021).

Studi yang menganalisis tentang determinan profitabilitas BUS telah dilakukan dalam banyak studi dengan hasil yang beragam. Wardana and Widyarti (2015); Pardede and Pangestuti (2016); Khoirunnisa, Rodhiyah, and Saryadi (2016) telah melakukan pengujian hubungan CAR dengan ROA. Rachmat and Komariah (2017); Munir (2018); Suwarno and Muthohar (2018) telah melakukan pengujian hubungan NPF dengan ROA. Haq (2015); Yusriani (2018); Achmad (2018); Setiani, Gagah, and Fathoni (2018); Pinasti and Mustikawati (2018); Suwarno and Muthohar (2018) sudah melakukan pengujian hubungan BOPO dengan ROA. Pardede and Pangestuti (2016); Wibisono and Wahyuni (2017); Almunawwaroh and Marliana (2018); Suwarno and Muthohar (2018); Hermawan and Fitria (2019); Lidyah et al. (2019) sudah melakukan pengujian hubungan FDR dengan ROA. 
Berdasarkan data OJK (2021) mengenai ketidakstabilan ROA atau laba bersih perbankan syariah serta beragamnya hasil studi sebelumnya maka perlu dilakukan penelitian lebih lanjut sehingga dapat memberikan bukti-bukti baru dengan melakukan pengujian pada tahun yang berbeda dengan menggunakan variabel dan indikator serta alat pengujian yang berbeda agar dapat menjaga kestabilan dan mengetahui faktor dalam meningkatkan nilai $R O A$ di tahun-tahun berikutnya. Selain itu penelitian ini bertujuan untuk menganalisis pengaruh $C A R$, $N P F$ serta BOPO terhadap ROA dan FDR sebagai variabel intervening sehingga dapat melengkapi dan menjembatani inkonsistensi hasil studi sebelumnya.

\section{TELAAH LITERATUR}

Teori signal menjelaskan seberapa penting pengukuran kinerja dan juga membahas bagaimana penyampaian bentuk sinyal-sinyal keberhasilan maupun kegagalan dari pihak manajemen (agent) kepada pihak pemilik (principal) yaitu para investor dan pelaku bisnis (stakeholder). Informasi merupakan hal yang sangat penting sebagai gambaran masalalu dan prediksi masa depan untuk kelangsungan hidup perusahaan, sehingga keakuratan sebuah informasi menjadi urgency dalam sebuah pengambilan tindakan dan keputusan (Pangestika and Musdholifah 2018). Baik dan buruk pengelolaan aset bank dapat tercermin melalui nilai rasio keuangan data annual report perusahaan, ketika pengelolaanya baik maka hal tersebut akan memberi sinyal positif kepada nasabah sehingga akan meningkatkan kepercayaan maupun loyalitas, begitupun sebaliknya ketika pengelolaan aset bank buruk maka hal tersebut akan memberikan sinyal negatif yang menandakan bahwa bank belum efisien dalam mengelola aset (Triyani 2018).

\section{Profitabilitas $(\mathrm{ROA})$}

Profitabilitas merupakan kemampuan mendapatkan laba bagi sebuah perusahaan, profitabilitas juga digunakan sebagai tingkat ukuran efektivitas pada suatu perusahaan karena apabila perusahaan menghasilkan keuntungan yang tinggi, artinya perusahaan mampu mengelola sumber daya yang ada dengan baik. Salah satu alat ukur untuk menentukan profitabilias adalah dengan menggunakan $R O A$ (Harahap et al. 2017). Perusahaan yang efisien dalam pengelolaan aktivanya akan menunjukan nilai ROA yang semakin tinggi (Pertiwi and Suryaninsih 2018). $R O A$ dipakai sebagai tolok ukur utama keberhasilan sebuah perusahaan karena ROA menggambarkan laba bersih yang telah disesuaikan dengan biaya operasional yang dikeluarkan (Wijaya 2019).

\section{Capital Adequacy Ratio (CAR)}

$C A R$ merupakan perbandingan anatara rasio kecukupan modal minimum dengan memperhitungkan market risk (Maharani and Chalid 2013). CAR dibutuhkan oleh pihak agen dan dikelola semaksimal mungkin oleh manajemen untuk bisa mendapatkan $R O A$ yang diharapkan oleh pihak principal. Nilai $C A R$ yang meninggi akan meningkatkan keuntungan bank, hal tersebut karena modal bank mencukupi sehingga kondisi dan lingkup usaha bank akan menjadi lebih stabil. Jadi, ketika $C A R$ menunjukan kenaikan nilai maka bank tersebut akan bisa membiayai seluruh kegiatan operasional dan mampu menghadapi kemungkinan 
risiko yang ada, sehingga hal tersebut akan berkontribusi besar untuk peningkatan profitabilitas (Yusriani 2018). Studi yang dilakukan oleh Khoirunnisa, Rodhiyah, and Saryadi (2016); Pardede and Pangestuti (2016); Munir (2018); Suwarno and Muthohar (2018) menemukan bahwa CAR mempunyai pengaruh positif terhadap $R O A$, sehingga dapat dirumuskan hipotesis pertama $\mathrm{H}_{1}: C A R$ berpengaruh positif terhadap $R O A$.

\section{Non Performing Financing (NPF)}

Pengelolaan keuangan yang baik akan memberikan sinyal positif bagi para stakeholder (Ayu and Suarjaya 2017). NPF tinggi menandakan penyaluran pembiayaan yang disalurkan oleh pihak agen memiliki kualitas buruk, karena $N P F$ tinggi mengindikasi banyak pembiayaan bermasalah sehingga pendapatan bank syariah berkurang dan berakibat pada turunnya nilai $R O A$ yang diharapkan oleh pihak principal (Angraini 2018). Pembiayaan bermasalah akan menyebabkan pengurangan pendapatan dan memperlambat pengembalian modal karena modal digunakan untuk menutup kerugian (Ljube 2017). Ketika bank memiliki tingkat pengembalian rendah maka akan berpengaruh terhadap penurunan laba bersih (ROA) (Ljube 2017). Kualitas pembiayaan yang rendah memungkinkan kondisi suatu bank bermasalah, sehingga ketika $N P F$ menunjukan angka yang tinggi itu bisa mengurangi profitabilitas (Pangestika and Musdholifah 2018). Studi dari Putrianingsih and Yulianto (2016); Rachmat and Komariah (2017); Setiani, Gagah, and Fathoni (2018) menemukan bahwa NPF mempengaruhi ROA secara negatif, sehingga dapat dirumuskan hipotesis kedua $\mathrm{H}_{2}: N P F$ berpengaruh negatif terhadap $R O A$.

\section{Biaya Operasional Terhadap Pendapatan Operasional (BOPO)}

Pihak agen dalam menjalankan kegiatan operasionalnya untuk mendapatkan $R O A$ bagi para pihak principal pasti mengeluarkan biaya yang disebut BOPO. BOPO tinggi artinya bank mengeluarkan banyak biaya untuk kegiatan operasional dan ketika hal tersebut tidak seimbang dengan pendapatan yang diterima akan menyebabkan berkurangnya keuntungan bagi pihak agen maupun principal. BOPO yang mempunyai angka tinggi, juga menunjukan makin kurang efisiensi bank tersebut ketika menjalankan dan melaksanakan kegiatan operasionalnya. Semakin tinggi nilai BOPO, maka semakin besar biaya yang dikeluarkan bank untuk kegiatan operasionalnya. Hal tersebut akan menurunkan keuntungan yang akan diperoleh bank (Harun 2016). Studi dari Haq (2015); Pinasti and Mustikawati (2018); Suwarno and Muthohar (2018) menemukan ROA dipengaruhi oleh BOPO secara negatif, sehingga dapat dirumuskan hipotesis ketiga $\mathrm{H}_{3}$ : BOPO berpengaruh negatif terhadap $R O A$.

\section{Financing to Deposit Ratio (FDR)}

FDR merupakan tingkat likuiditas yang dimiliki oleh bank syariah sebagai pihak agen atau pengelola (Armereo 2015). Nilai $F D R$ tidak boleh terlalu tinggi dan tidak boleh terlalu rendah, $F D R$ pada tingkat porsi yang pas sesuai standar BI, akan memberikan laba bersih atau ROA yang tinggi seperti yang diharapkan oleh pihak principal atau pemilik dana, FDR juga bisa menunjukkan seberapa banyak pembiayaan yang disalurkan kepada nasabah (Sabtatianto and Yusuf 2018). 
Ketika angka rasio $C A R$ semakin naik maka hal tersebut akan berpengaruh terhadap peningkatan aktifitas pembiayaan dan likuiditas $(F D R)$. Hal tersebut terjadi karena ketika bank memiliki modal yang tinggi, akan semakin banyak penyaluran modal tersebut untuk kegiatan pembiayaan, sehingga ketika $C A R$ tinggi akan berpengaruh terhadap FDR secara positif (Ervina and Ardiansari 2016). Hal tersebut juga didukung oleh hasil studi Edo and Wiagustini (2014); Ariyanti, Paramita, and Pranaditya (2017); Fitria (2017) yang menemukan bahwa $C A R$ mempengaruhi $F D R$ secara positif, sehingga dapat dirumuskan hipotesis keempat $\mathrm{H}_{4}$ : $C A R$ berpengaruh positif terhadap $F D R$.

Ketika $N P F$ menunjukkan angka semakin tinggi pada suatu pembiayaan yang disalurkan oleh bank, maka hal tersebut akan mengakibatkan menurunnya $F D R$ karena ketika semakin banyak pembiayaan yang macet, bank akan semakin sulit untuk membayar kewajiban kepada pihak ketiga, sehingga bank akan mengurangi jumlah pembiayaan. Dalam arti lain, $N P F$ yang makin tinggi akan menurunkan tingkat likuiditas (Harun 2016). Studi dari Edo and Wiagustini (2014); Ervina and Ardiansari (2016); Hasbidin and Siregar (2017); Sengkey, Murni, and Tulung (2018) menemukan bahwa NPF mempengaruhi FDR secara negatif, sehingga dapat dirumuskan hipotesis kelima $\mathrm{H}_{5}: N P F$ berpengaruh negatif terhadap FDR.

Ketika rasio BOPO semakin kecil maka hal tersebut menunjukan bahwa pengelolaan manajemen semakin efisien, sehingga kemungkinan bank berada diposisi bermasalah semakin rendah, BOPO yang rendah menunjukan indikasi kesehatan bank. Semakin sehat bank, masyarakat akan semakin merasa aman untuk menanamkan modalnya untuk dikelola oleh pihak bank sehingga penyaluran pembiayaan bank semakin tinggi (Hasbidin and Siregar 2017). Studi dari Hasbidin and Siregar (2017); Sengkey, Murni, and Tulung (2018) menemukan bahwa FDR dipengaruhi BOPO secara negatif, sehingga dapat dirumuskan hipotesis keenam $\mathrm{H}_{6}$ : $\mathrm{BOPO}$ berpengaruh negatif terhadap FDR.

$F D R$ merupakan rasio yang menggambarkan total seluruh pembiayaan kepada nasabah dengan dana pihak ketiga (deposito, giro dan tabungan) yang diterima oleh bank. Ketika bank mendapatkan dan menampung banyak dana, bank juga harus banyak memutar kembali dana itu melalui pembiayaan, jadi dana pihak ketiga dan juga pembiayaan haruslah seimbang (Somantri and Sukmana 2019). Angka FDR yang tinggi mengharuskan bank untuk tinggi juga dalam menyalurkan pembiayaan sehingga akan meningkatkan keuntungan atau profiabilitas (Harun 2016). Studi dari Riyadi and Yulianto (2014); Almunawwaroh and Marliana (2018); Suwarno and Muthohar (2018); Hermawan and Fitria (2019) menemukan bahwa FDR mempengaruhi ROA secara signifikan dan positif, sehingga dapat dirumuskan hipotesis ketujuh $\mathrm{H}_{7}$ : $F D R$ berpengaruh positif terhadap $R O A$.

Bank yang memiliki $C A R$ tinggi menunjukkan bahwa bank tersebut mempunyai kemampuan menglola risiko yang kuat. Hal tersebut akan meningkatkan jumlah pembiayaan sehingga semakin tinggi CAR akan meningkatkan tingkat penyaluran pembiayaan pula yang akan meningkatkan laba $(R O A)$. Begitupun sebaliknya ketika penyaluran pembiayaan rendah maka bank akan kehilangan kesempatan untuk memperoleh keuntungan (ROA) (Pardede and Pangestuti 2016). Studi dari Edo and Wiagustini (2014); Ervina and Ardiansari (2016); Ariyanti, Paramita, and Pranaditya (2017); Fitria (2017) menemukan 
bahwa $C A R$ mempengaruhi $F D R$ secara positif sehingga dapat dirumuskan hipotesis kedelapan $\mathrm{H}_{8}$ : FDR mampu memediasi pengaruh $C A R$ terhadap $R O A$.

$N P F$ menunjukkan pembiayaan bermasalah pada bank syariah, semakin bertambahnya pembiayaan bermasalah membuat bank tidak berani untuk menambah penyaluran pembiayaan lagi, sehingga ketika NPF menunjukkan kenaikan angka maka akan makin buruk kualitas pembiayaan milik bank syariah, kemudian menyebabkan penurunan $F D R$ sebagai bentuk tindakan yang dilakukan bank syariah dalam rangka menurunkan nilai $N P F$, dan akhirnya mengakibatkan bank menjadi rugi (Almunawwaroh and Marliana 2018). Studi dari Ervina and Ardiansari (2016); Hasbidin and Siregar (2017); Sengkey, Murni, and Tulung (2018) menemukan bahwa NPF mempengaruhi FDR secara negatif. Serta diiringi hasil studi Riyadi and Yulianto (2014); Almunawwaroh and Marliana (2018); Suwarno and Muthohar (2018); Hermawan and Fitria (2019) yang menemukan bahwa $F D R$ mempengaruhi $R O A$ secara signifikan, sehingga dapat dirumuskan hipotesis kesembilan $\mathrm{H}_{9}$ : $F D R$ mampu memediasi pengaruh $N P F$ terhadap $R O A$.

Biaya efisiensi operasional suatu bank akan berpengaruh kepada cara kerja bank itu sendiri. Makin kecil biaya operasional yang dikeluarkan, menunjukkan bank tersebut memiliki kapasitas kerja yang baik. Kinerja bank yang baik akan membuat masyarakat percaya untuk menanam dana pada suatu bank sehingga penyaluran pembiayaan meningkat dan profitabilitas juga akan meningkat (Pinasti and Mustikawati 2018). Studi dari Hasbidin and Siregar (2017); Sengkey, Murni, and Tulung (2018) menemukan BOPO mempengaruhi FDR secara negatif. Serta diiringi oleh studi dari Riyadi and Yulianto (2014); Almunawwaroh and Marliana (2018); Suwarno and Muthohar (2018); Hermawan and Fitria (2019) yang menemukan bahwa FDR mempengaruhi $R O A$ secara signifikan, sehingga dapat dirumuskan hipotesis kesepuluh $\mathrm{H}_{10}$ : FDR mampu memediasi pengaruh $\mathrm{BOPO}$ terhadap ROA.

\section{Gambar 1 Kerangka Pemikiran}

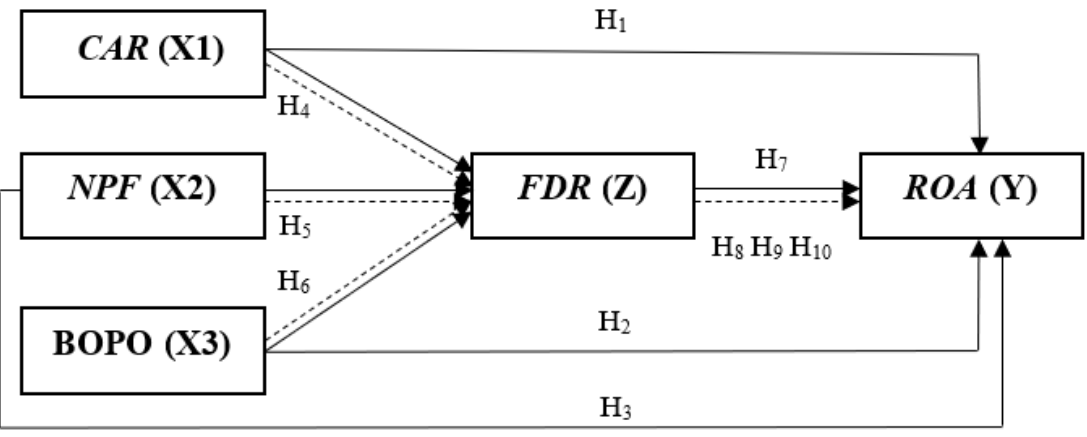

\section{METODE PENELITIAN}

Penelitian ini dilakukan dengan menggunakan pendekatan kuantitatif dengan data panel. Penelitian kuantitatif dijelaskan sebagai penelitian empirik dimana datanya berbentuk angka-angka. Penelitian ini memakai jenis data sekunder dengan menggunakan rasio keuangan yang meliputi Capytal Adequacy Ratio (CAR), Non Performing Financing (NPF), Biaya Operasional terhadap 
Pendapatan Operasional (BOPO), Financing to Deposit Ratio (FDR) dan Return on Assets (ROA).

Populasi penelitian ini berjumlah 14 bank umum syariah di Indonesia. Sedangkan pengambilan sampel menggunakan teknik purposive sampling. Sampel yang diambil harus mewakili variabel data yang dipakai untuk melakukan penelitian selama periode pengamatan. Pada penelitian ini, sampel yang dipakai adalah bank umum syariah yang memenuhi beberapa kriteria yaitu: (1) Bank umum syariah yang sudah terdaftar di bank Indonesia dan otoritas jasa keuangan; (2) Bank yang tidak dalam dicabut ijinnya/ kondisi peralihan kepemilikan; (3) Tersedia variabel data lengkap yang berkaitan dengan penelitian dalam periode pengamatan. Mengacu pada kriteria tersebut, maka bank yang dapat diambil menjadi sampel untuk penelitian ini adalah 11 bank umum syariah di Indonesia yaitu Bank Aceh Syariah, Bank Muamalat Indonesia, Bank Victoria Syariah, BRI Syariah, BNI Syariah, Bank Syariah Mandiri, Bank Mega Syariah, Bank Syariah Bukopin, BCA Syariah, BTPN Syariah dan Bank Panin Dubai Syariah.

Data diambil melalui annual report masing-masing bank syariah periode 2015-2019 yang diakses melalui website resmi masing-masing bank yang bersangkutan. Data diolah memakai program Eviews 9 dengan analisis jalur (path analisys), kemudian data dianalisis menggunakan regresi linear berganda dan analisis jalur. Terdapat 2 regresi linear berganda dalam penelitian ini yaitu: Persamaan 1: $\mathrm{Y}=\beta 0+\beta 1 . C A R+\beta 2 . N P F+\beta 3 . \mathrm{BOPO}+\beta 4 . F D R+\mathrm{e}$ dan Persamaan 2: $\mathrm{Z}=\beta 0+\beta 1 . C A R+\beta 2 . N P F+\beta 3 . \mathrm{BOPO}+\mathrm{e} 2$

\section{HASIL DAN PEMBAHASAN PENELITIAN}

\section{Uji Normalitas}

Berdasarkan hasil perhitungan uji normalitas persamaan 1 ROA (Y), menunjukkan bahwa nilai Jearque-Bera sebesar 0,729076 dan nilai probability sebesar 0,694518>0,05 yang mengindikasikan bahwa data berdistribusi normal. Berdasarkan hasil perhitungan uji normalitas persamaan 2 FDR (Z), menunjukkan bahwa nilai Jearque-Bera sebesar 0,729076 dan nilai probability sebesar $0,396279>0,05$ yang mengindikasikan bahwa data berdistribusi normal.

\section{Uji Regresi Pemilihan Model}

Uji Chow dilakukan guna mengetahui dan memilih model yang cocok diantara common effect dan fixed effect pada regresi data panel. Berdasarkan hasil uji Chow didapat nilai probability sebesar 0,0001, oleh sebab nilai probability < 0,05 maka model regresi yang digunakan adalah fixed effect model. Uji Hausman dilakukan mengetahui apakah data panel memiliki efek random. Uji Hausman digunakan untuk membandingkan model yang terbaik antara fix effect atau random effect. Berdasarkan hasil uji Hausman didapat nilai probability sebesar 0,0000 , oleh sebab nilai probability $<0,05$ maka model regresi yang digunakan adalah fixed effect model.

Hasil pengujian kelayakan model dan koefisien determinasi serta uji hipotesis disajikan pada Tabel 1 dan Tabel 2. Kelayakan model diuji dan dievaluasi berdasarkan nilai probability secara simultan. Pada Tabel 1 nilai probability secara simultan menunjukkan nilai sebesar 0,00 , dimana nilai 
probability $<0,05$. Dengan demikian dapat dikatakan bahwa model layak digunakan sebagai model prediksi. Koefisien determinasi ditunjukkan oleh nilai Adjusted $R$-Squared sebesar 0,97 atau sama dengan 97\%, sehingga kemampuan variabel $C A R, N P F$, BOPO dan FDR dalam mempengaruhi ROA adalah sebesar 97\% dan sisanya sebesar 3\% dipengaruhi oleh variabel lain di luar penelitian ini. Sedangkan pada Tabel 2 nilai probability secara simultan menunjukkan nilai sebesar 0,156, dimana nilai probability > 0,05. Dengan demikian dapat dikatakan bahwa model belum layak digunakan sebagai model prediksi. Hal ini dibuktikan dengan nilai koefisien determinasi yang ditunjukkan oleh nilai Adjusted $R$ Squared sebesar 0,05 atau sama dengan 5\% sehingga kemampuan variabel CAR, $N P F$ dan BOPO yang dimediasi oleh FDR dalam mempengaruhi ROA hanya sebesar 5\% dan sisanya sebesar $95 \%$ dipengaruhi oleh variabel lain di luar penelitian ini.

Tabel 1 Fixed Effect Model (Persamaan 1)

\begin{tabular}{lcccc}
\hline Variable & Coefficient & Std. Error & t-Statistic & Prob. \\
\hline Constant & 0,156734 & 0,076743 & 2,042317 & 0,0503 \\
CAR & $-1,27 \mathrm{E}-05$ & 0,017004 & $-0,000746$ & 0,9994 \\
NPF & $-0,007976$ & 0,079050 & $-0,100902$ & 0,9203 \\
BOPO & $-0,091296$ & 0,003075 & $-29,69398$ & 0,0000 \\
FDR & 0,013066 & 0,012466 & 1,048110 & 0,3032 \\
\hline Prob $(F-S t a t i s t i c)$ & & & 0,000000 \\
Adjusted R-Squared & & & 0,970956 \\
\hline
\end{tabular}

Sumber: data sekunder (diolah)

Tabel 2 Fixed Effect Model (Persamaan 2)

\begin{tabular}{lcccc}
\hline Variable & Coefficient & Std. Error & t-Statistic & Prob. \\
\hline Constant & $-2,849394$ & 0,983155 & $-2,898215$ & 0,0061 \\
CAR & $-0,014070$ & 0,224664 & $-0,062626$ & 0,9504 \\
NPF & $-2,286988$ & 0,979694 & $-2,334391$ & 0,0247 \\
BOPO & 0,031367 & 0,043697 & 0,717829 & 0,4770 \\
\hline \multicolumn{2}{l}{ Prob(F-Statistic) } & & & 0,156500 \\
Adjusted R-Squared & & & 0,054987 \\
\hline
\end{tabular}

Sumber: data sekunder (diolah)

Berdasarkan Tabel 1 dapat dibentuk persamaan regresi yaitu: $\mathrm{Y}=\beta 0+$ $\beta 1 . X 1+\beta 2 . X 2+\beta 3 . X 3+\beta 4 . Z=0,156734-1,27 \mathrm{E}-05(C A R)-0,007976(N P F)$ $-0,091296(\mathrm{BOPO})+0,013066(F D R)$. Model regresi tersebut dapat dijabarkan yakni: (1) Konstanta yang dihasilkan yaitu 0.156734 yang artinya ketika variabel bebas sejumlah nol (0), ROA akan menunjukan kenaikan 0,156734. (2) Koefisien regresi variabel $C A R$ adalah $-1,27 \mathrm{E}-05$ berarah negatif, artinya ketika $C A R$ mengalami kenaikan 1 satuan, maka $R O A$ akan turun -1.27E-05 dengan anggapan variabel lainnya tetap. (3) Koefisien regresi variabel $N P F$ adalah $-0,007976$ berarah negatif, artinya ketika $N P F$ mengalami kenaikan 1 satuan, $R O A$ akan turun -0,007976 dengan anggapan variabel lainnya tetap. (4) Koefisien regresi variabel BOPO adalah - 0,091296 berarah negatif, artinya ketika BOPO mengalami kenaikan 1 satuan, maka ROA akan turun -0,091296 dengan anggapan variabel lainnya tetap. (5) Koefisien regresi $F D R$ adalah 0,013066 berarah positif, artinya ketika $F D R$ mengalami kenaikan 1 satuan, maka $R O A$ akan naik sebesar 0,013066 dengan anggapan variabel lainnya tetap. 
Berdasarkan Tabel 2 dapat dibentuk persamaan regresi yaitu: $\mathrm{Z}=\beta 0+$ $\beta 1 . \mathrm{X} 1+\beta 2 . \mathrm{X} 2+\beta 3 . \mathrm{X} 3=-2,849394-0,014070(C A R)-2,286988(N P F)+$ 0,031367 (BOPO). Model regresi tersebut dapat dijabarkan yakni: (1) Konstanta yang dihasilkan yaitu $-2,849394$ artinya ketika variabel bebas sejumlah (0), FDR akan turun sejumlah -2,849394. (2) Koefisien regresi CAR yakni -0,014070 berarah negatif, artinya ketika variabel $C A R$ mengalami kenaikan 1 satuan, maka $F D R$ akan turun sejumlah -0,014070 dengan anggapan variabel lainnya tetap. (3) Koefisien regresi $N P F$ yakni $-2,286988$ berarah negatif, artinya ketika variabel NPF mengalami kenaikan 1 satuan, maka FDR akan turun sejumlah -2,286988 dengan anggapan variabel lainnya tetap. (4) Koefisien regresi variabel BOPO yakni 0,031367 berarah positif, artinya ketika BOPO mengalami kenaikan sebesar 1 satuan, maka $F D R$ akan naik sejumlah 0,031367 dengan anggapan variabel lainnya tetap.

\section{Path Analisys (Analisis Jalur)}

Analisis jalur dipakai guna mencari tahu bagaimana pengaruh langsung ataupun pengaruh tak langsung variabel bebas terhadap variabel dependen (Suliyanto 2011). Pengaruh mediasi dapat diketahui dengan melihat hasil perkalian koefisien $\mathrm{p}^{2} \mathrm{x} \mathrm{p}^{3}$. Sedangkan, untuk menguji signifikansi menggunakan sobel test:

$$
\mathrm{Sp} 2 \mathrm{p} 3=\sqrt{p 3^{2} s p 2^{2}+p 2^{2} s p 3^{2}+s p^{2} s p 3^{2}}
$$

Menghitung $t_{\text {hitung }}$ digunakan untuk melihat bagaimana pengaruh mediasi terhadap variabel yang dimediasi dengan menggunakan rumus:

$$
\mathrm{t}=\frac{p 2 p 3}{S p 2 p 3}
$$

\section{Gambar 2 Model Path Analisys}

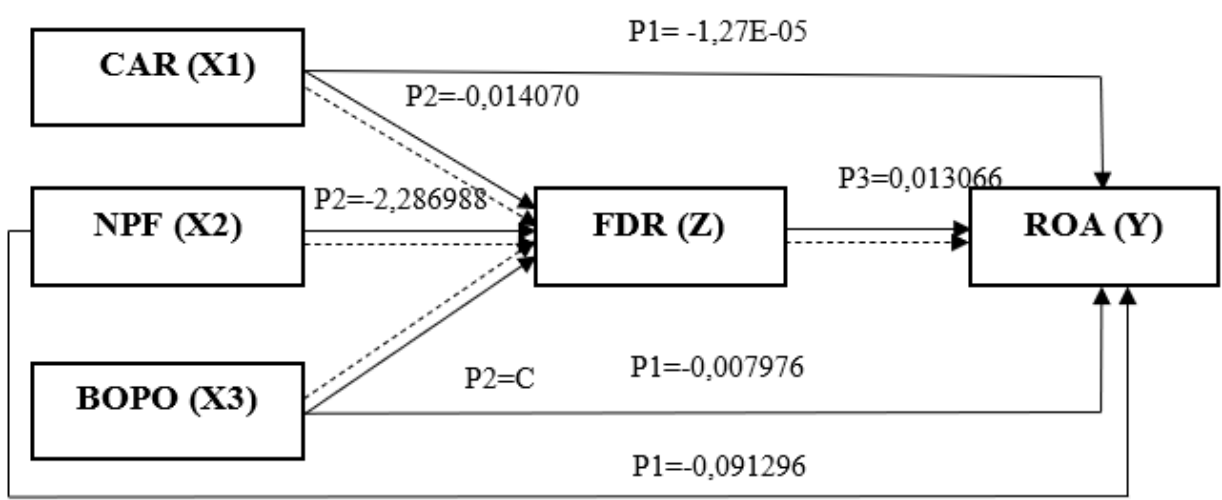

Berdasarkan Tabel 1 dan Tabel 2 dapat dijelaskan model path analisys adalah sebagai berikut: (1) Pengaruh langsung $C A R$ terhadap $R O A=-1,27 \mathrm{E}-05$. (2) Pengaruh langsung $N P F$ terhadap $R O A=-0,007976$. (3) Pengaruh langsung BOPO terhadap $R O A=-0,091296$. (4) Pengaruh tidak langsung $C A R$ dengan $R O A=(-0,014070) \times(0,013066)=-0,000183839$. (5) Pengaruh total $C A R$ dengan $R O A=(-1,27 \mathrm{E}-05)+0,000183839=-0,00019654$. (6) Pengaruh tidak langsung $N P F$ dengan $R O A=(-2,286988) \times(0,013066)=-0,029881785$. (7) Pengaruh total 
$N P F$ dengan $R O A=(-0,007976)+(-0,029881785)=-0,03785779$. (8) Pengaruh tidak langsung BOPO dengan $R O A=(0,013066) \times(0,013066)=0,000409841$. (9) Pengaruh total BOPO dengan $R O A=(-0,091296)+0,000409841=-0,08719759$.

\section{Uji Hipotesis}

Berdasarkan Tabel 1 dapat dilihat bahwa nilai probability dari variabel $C A R$ sebesar 0,9994, yang mana nilai probability > 0,05 dan nilai koefisien negatif, sehingga $\mathrm{H}_{1}$ ditolak. Nilai probability dari variabel $N P F$ sebesar 0,9203, yang mana nilai probability $>0,05$ dan nilai koefisien negatif, sehingga $\mathrm{H}_{2}$ diterima. Nilai probability dari variabel BOPO yakni 0,0000, yang mana nilai probability $<0,05$ dan nilai koefisien negatif, sehingga $\mathrm{H}_{3}$ diterima. Nilai probability variabel $F D R$ sebesar 0,303, yang mana nilai probability $>0,05$ dan nilai koefisien positif, sehingga $\mathrm{H}_{7}$ diterima. Berdasarkan Tabel 2 dapat dilihat nilai probability dari variabel $C A R$ sebesar 0,9504 , yang mana nilai probability > 0,05 dan nilai koefisien negatif, sehingga $\mathrm{H}_{4}$ ditolak. Nilai probability dari variabel $N P F$ sebesar 0,0247 , yang mana nilai probability $<0,05$ dan nilai koefisien negatif, sehingga $\mathrm{H}_{5}$ diterima. Nilai probability dari variabel BOPO sebesar 0,4770, yang mana nilai probability > 0,05 dan nilai koefisien positif, sehingga $\mathrm{H}_{6}$ ditolak.

Berdasarkan Gambar 2 dapat dihitung nilai $t_{\text {hitung }}$ menggunakan sobel test, dimana nilai $t_{\text {tabel }}$ diketahui sebesar 1,67303 , jika nilai $t_{\text {hitung }}>t_{\text {tabel }}$ dengan signifikansi 5\%, maka terdapat pengaruh mediasi. Variabel $C A R$ dimediasi oleh $F D R$ didapat nilai $\mathrm{p} 2 \mathrm{p} 3=-0,00018384$ dan $\mathrm{sp} 2 \mathrm{p} 3=0,00406096, \mathrm{t}_{\text {hitung }}=$ $\mathrm{p} 2 \mathrm{p} 3 / \mathrm{Sp} 2 \mathrm{p} 3=-0,00018384 / 0,00406096=-0,04527$, yang mana $\mathrm{t}_{\text {hitung }}<\mathrm{t}_{\text {tabel }}(-$ $0,04527<1,67303)$, sehingga $\mathrm{H}_{8}$ ditolak. Variabel $N P F$ dimediasi oleh FDR didapat nilai $\mathrm{p} 2 \mathrm{p} 3=-0,02988179$ dan $\mathrm{sp} 2 \mathrm{p} 3=0,033553068, \mathrm{t}_{\text {itung }}=\mathrm{p} 2 \mathrm{p} 3 / \mathrm{Sp} 2 \mathrm{p} 3$ $=-0,02988179 / 0,033553068=-0,89058$, yang mana $t_{\text {hitung }}<t_{\text {tabel }}(-0,89058<$ 1,67303), sehingga $\mathrm{H}_{9}$ ditolak. Variabel BOPO dimediasi oleh $F D R$ didapat nilai $\mathrm{p} 2 \mathrm{p} 3=0,000409841$ dan Sp2p3 $=0,000880683, \mathrm{t}_{\text {hitung }}=\mathrm{p} 2 \mathrm{p} 3 / \mathrm{sp} 2 \mathrm{p} 3=$ $0,000409841 / 0,000880683=0,465367$, yang mana $t_{\text {hitung }}<t_{\text {tabel }}(0,465367<$ 1,67303), sehingga $\mathrm{H}_{10}$ ditolak.

\section{Pengaruh CAR Terhadap ROA}

Hasil hipotesis pertama $\mathrm{H}_{1}$ ditolak, ini berarti bahwa $C A R$ mempengaruhi $R O A$ secara negatif dan tidak signifikan, ketika angka $C A R$ naik maka $R O A$ akan turun. $C A R$ merupakan salah satu rasio yang menunjukkan kecukupan modal bank dengan membandingkan modal bank dengan aktiva tertimbang menurut risiko. Aktiva tertimbang yang memiliki risiko tertinggi adalah pembiayaan. Ketika bank syariah mencairkan pembiayaan, bank akan melakukan pencadangan dana untuk menanggulangi adanya risiko pembiayaan bermasalah. CAR tinggi mengindikasi bank tak banyak melakukan pencadangan dana untuk mengantisipasi adanya risiko pembiayaan, sehingga bisa dikatakan bahwa bank tersebut tidak banyak melakukan pembiayaaan yang akhirnya menurunkan profitabilitas. Disisi lain, kepercayaan masyarakat kepada bank menjadi faktor yang paling penting dalam peningkatan laba bank. Karena meskipun bank memiliki angka modal yang tinggi, jika masyarakat tidak memiliki kepercayaan kepada bank, bank syariah tidak akan mampu memutarkan dana untuk investasi ataupun pembiayaan sehingga nilai $R O A$ akan menurun. Sampel dalam periode penelitian juga menunjukan bahwa 
setiap kenaikan CAR tidak diikuti dengan penurunan ROA. Hasil penelitian in selaras dengan studi yang dilakukan oleh Wardana and Widyarti (2015); Putrianingsih and Yulianto (2016); Pinasti and Mustikawati (2018) yang menemukan hasil bahwa $C A R$ berpengaruh negatif terhadap ROA. Hasil penelitian ini tidak sejalan dengan studi yang dilakukan oleh Khoirunnisa, Rodhiyah, and Saryadi (2016); Pardede and Pangestuti (2016); Munir (2018); Suwarno and Muthohar (2018) menemukan bahwa CAR mempunyai pengaruh positif terhadap $R O A$.

\section{Pengaruh NPF Terhadap ROA}

Hasil hipotesis kedua $\mathrm{H}_{2}$ diterima, ini berarti bahwa $N P F$ mempengaruhi $R O A$ secara negatif namun tidak signifikan. Jadi semakin tinggi nilai $N P F$ maka nilai $R O A$ akan semakin rendah. $N P F$ menggambarkan tingkat pembiayaan non lancar, $N P F$ tinggi disebabkan banyak pembiayaan bermasalah dalam operasional bank, padahal pembiayaan merupakan sumber utama pendapatan bank syariah. sehingga, ketika banyak pembiayaan yang memiliki kolektabilitas buruk akan menyebabkan keuntungan bank menurun. Namun tingginya $N P F$ tidak dapat menjadi satu-satunya tolok ukur penurunan keuntungan, karena peningkatan $N P F$ pada satu periode tidak langsung memberikan penurunan keuntungan pada periode tersebut. Pada dasarnya $R O A$ turun karena berkurangnya pengembalian dana pihak ketiga (DPK) yang seharusnya disalurkan lagi kepada nasabah. Ketika penyaluran DPK turun otomatis keuntungan bank juga akan menurun. Penurunan angka DPK dapat terjadi karena keterlambatan pengembalian kewajiban nasabah, faktor eksternal seperti seperti kondisi ekonomi, bunga bank dan perbedaan minat masyarakat untuk menanamkan dananya pada setiap bank. Hasil penelitian ini selaras dengan penelitian Putrianingsih and Yulianto (2016); Rachmat and Komariah (2017); Setiani, Gagah, and Fathoni (2018) menemukan bahwa NPF mempengaruhi ROA secara negatif dan riset dari Lemiyana and Litriani (2016) yang menemukan NPF tidak signifikan dengan ROA.

\section{Pengaruh BOPO Terhadap ROA}

Hasil hipotesis ketiga $\mathrm{H}_{3}$ diterima, ini berarti bahwa BOPO mempengaruhi $R O A$ secara negatif dan signifikan, ketika nilai BOPO mengalami penurunan, maka nilai $R O A$ akan meningkat. BOPO merupakan rasio yang membandingkan seluruh beban operasional yang dikeluarkan dengan seluruh pendapatan operasional yang diterima, dengan maksud mengetahui baik buruknya kemampuan bank syariah dalam mengelola beban operasional. Beban operasional mencakup seluruh biaya yang dikeluarkan bank syariah dalam seluruh kegiatannya seperti biaya pemasaran, gaji karyawan, beban bagi hasil, beban bonus titipan wadiah, beban penurunan nilai surat berharga dan beban operasional lainnya. Sedangkan pendapatan operasional mecakup seluruh pendapatan yang diterima bank seperti pendapatan atas pengelolaan dana oleh bank sebagai mudharib, hak bagi hasil atas dana syirkah dan pendapatan operasional lainnya. Angka BOPO yang tinggi mengindikasi bank mengeluarkan banyak biaya dalam kegiatan operasionalnya, ketika pengeluaran tinggi namun tidak sebanding dengan pendapatan, hal tersebut akan mengakibatkan penurunan keuntungan. Ketika angka BOPO terus meningkat artinya manajemen tidak efisien dalam pengelolaan kegiatan operasionalnya. Hasil penelitian ini selaras dengan studi Haq (2015); 
Pinasti and Mustikawati (2018); Suwarno and Muthohar (2018) menemukan ROA dipengaruhi oleh BOPO secara negatif.

\section{Pengaruh CAR Terhadap FDR}

Hasil hipotesis keempat $\mathrm{H}_{4}$ ditolak, ini berarti bahwa $C A R$ berpengaruh negatif dan tidak signifikan terhadap $F D R$, semakin tinggi $C A R$ maka akan menurunkan nillai FDR. FDR digunakan untuk mengetahui tingkat likuiditas bank dengan cara membagi jumlah pembiayaan dengan DPK. Angka FDR rendah menunjukkan rendahnya bank dalam penyaluran pembiayaan. Pembiayaan rendah dapat terjadi karena peningkatan pembiayaan bermasalah sehingga untuk menjaga kualitas pembiayaaan bank syariah memilih menyimpan kelebihan likuiditasnya untuk mendapatkan keuntungan dengan cara lain yaitu giro pada Bank Indonesia dan surat berharga SBI mengingat bahwa giro pada BI dan surat berharga SBI adalah aktiva tertimbang menurut risiko yang memiliki bobot $0 \%$. Sedangkan pembiayaan adalah aktiva tertimbang menurut risiko yang memiliki bobot risiko tinggi. Dalam kondisi tersebut bank mampu meningkatkan nilai $C A R$ tanpa harus menempatkan bank pada risiko yang tinggi. Selain itu meninjau kembali kepercayaan masyarakat kepada bank menjadi faktor yang paling penting bank dalam penyaluran pembiayaan. Semakin masyarakat tidak percaya terhadap bank, meskipun bank memiliki $C A R$ yang tinggi, pembiayaan akan tetap menunjukan angka yang rendah sehingga profitabilitas akan menurun. Hasil penelitian ini selaras dengan studi yang dilakukan oleh Fadila and Yuliani (2015) yang menemukan bahwa $C A R$ berpengaruh negatif terhadap FDR. Hasil penelitian ini bertolak belakang dengan hasil studi yang dilakukan oleh Edo and Wiagustini (2014); Ariyanti, Paramita, and Pranaditya (2017); Fitria (2017) yang menemukan bahwa $C A R$ mempengaruhi FDR secara positif.

\section{Pengaruh NPF Terhadap FDR}

Hasil hipotesis kelima $\mathrm{H}_{5}$ diterima, ini berarti bahwa $N P F$ mempengaruhi $F D R$ secara negatif dan signifikan. Peningkatan nilai $N P F$ akan menurunkan nilai $F D R$. NPF digunakan sebagai indikator untuk mendeteksi pembiayaan yang bermasalah. Ketika angka $N P F$ mengalami peningkatan artinya bank mengalami banyak pembiayaan yang bermasalah. Pada kondisi tersebut bank syariah akan melakukan strategi guna menjaga kualitas pembiayaannya, yaitu dengan cara mengurangi jumlah pembiayaan. Jumlah pembiayaan rendah akan mengurangi nilai $F D R$ mengingat rasio $F D R$ digunakan untuk mengetahui tinggi rendahnya penyaluran dana kepada nasabah. Sehingga apabila angka $N P F$ naik maka angka FDR akan turun. Hasil penelitian ini selaras dengan studi yang dilakukan oleh Edo and Wiagustini (2014); Ervina and Ardiansari (2016); Hasbidin and Siregar (2017); Sengkey, Murni, and Tulung (2018) menemukan bahwa NPF mempengaruhi FDR secara negatif.

\section{Pengaruh BOPO Terhadap FDR}

Hasil hipotesis keenam $\mathrm{H}_{6}$ ditolak, ini berarti bahwa BOPO berpengaruh positif dan tidak signifikan terhadap $F D R$, ketika angka BOPO naik maka $F D R$ juga akan mengalami kenaikan. FDR merupakan rasio yang menunjukkan tinggi rendahnya pembiayaan yang disalurkan. Sedangkan BOPO merupakan rasio untuk mengetahui biaya operasional yang dikeluarkan dengan cara 
membandingkan beban operasional dengan pendapatan operasional. Ketika biaya operasional tinggi, bank akan melakukan strategi untuk menurunkan angka tersebut agar tidak semakin membengkak, yaitu dengan cara meningkatkan pendapatan. Pembiayaan merupakan sumber pendapatan bank, sehingga bank harus meningkatkan penyaluran pembiayaan guna meng-cover dan mengimbangi biaya operasional yang tinggi, yang akan membuat $F D R$ juga mengalami kenaikan. Disisi lain bank tidak hanya meningkatkan pendapatan dengan meningkatkan pembiayaan, namun juga dengan investasi penanaman dana produktif seperti giro SBI, dana syirkah, dan pendapatan non-operasional lainnya. Hasil penelitian ini selaras dengan studi yang dilakukan oleh Astuti (2016) yang menemukan hasil bahwa BOPO berpengaruh positif terhadap FDR. Hasil penelitian ini bertolak belakang dengan studi dari Hasbidin and Siregar (2017); Sengkey, Murni, and Tulung (2018) menemukan bahwa FDR dipengaruhi BOPO secara negatif.

\section{Pengaruh FDR terhadap ROA}

Hasil hipotesis ketujuh $\mathrm{H}_{7}$ diterima, ini berarti bahwa $F D R$ berpengaruh positif tidak signifikan terhadap $R O A$, ketika $F D R$ naik maka $R O A$ juga akan mengalami kenaikan. FDR merupakan rasio yang biasa dipakai perbankan untuk mengetahui seberapa besar pembiayaan yang disalurkan. Angka FDR yang naik mengindikasi naiknya tingkat pembiayaan. Penyaluran pembiayaan yang semakin tinggi kepada nasabah akan berdampak pada pengembalian yang tinggi pula, sehingga hal tersebut akan meningkatkan profitabilitas. Namun disisi lain keuntungan bank tidak hanya diperoleh melalui pembiayaan melainkan dapat juga melalui bagi hasil atas dana syirkah, penempatan pada SBI, penempatan pada bank lain dan pendapatan non operasional lainnya. FDR tinggi dapat meningkatkan angka $R O A$ jika diimbangi dengan kualitas pembiayaan yang baik, dengan kolektabilitas rendah. Hasil penelitian ini selaras dengan studi yang dilakukan oleh Riyadi and Yulianto (2014); Almunawwaroh and Marliana (2018); Suwarno and Muthohar (2018); Hermawan and Fitria (2019) menemukan bahwa FDR berpengaruh positif terhadap ROA.

\section{FDR Sebagai Mediasi Pengaruh CAR Terhadap ROA}

Hasil hipotesis kedelapan $\mathrm{H}_{8}$ ditolak, artinya $F D R$ tidak dapat memediasi hubungan antara $C A R$ terhadap $R O A$ pada bank umum syariah. $C A R$ merupakan salah satu rasio yang menunjukkan kecukupan modal bank dengan membandingkan modal bank dengan aktiva tertimbang menurut risiko. Bank yang memiliki modal besar akan memiliki kemungkinan untuk tahan atas berbagai risiko, sehingga akan meningkatkan $R O A$. Namun, ketika modal bank terlalu tinggi artinya bank tidak memutarkan dana yang dimiliki dengan baik sehingga akan menyebabkan turunnya profitabilitas. $F D R$ merupakan rasio untuk mengukur seberapa besar penyaluran pembiayaan bank yang diberikan kepada nasabah. Pembiayaan menjadi sumber pendapatan bank guna peningkatan ROA. Tetapi hasil uji menunjukkan $F D R$ tidak memiliki pengaruh yang signifikan terhadap $R O A$. Maka $C A R$ tidak dapat mempengaruhi $R O A$ melalui tingkat likuiditas yang diukur oleh FDR. Hasil penelitian ini didukung oleh studi Wityasari and Pangastuti (2014); Fitria (2017) yang menemukan bahwa FDR tidak dapat 
memediasi hubungan antara $C A R$ dengan $R O A, C A R$ mampu mempengaruhi $R O A$ secara langsung.

\section{FDR Sebagai Mediasi Pengaruh NPF Terhadap ROA}

Hasil hipotesis kesembilan $\mathrm{H}_{9}$ ditolak, artinya $F D R$ tidak dapat memediasi hubungan antara $N P F$ terhadap $R O A$ pada bank umum syariah. $N P F$ merupakan indikator pembiayaan non lancar yang dimiliki bank, $N P F$ yang tinggi berarti penyaluran pembiayaan bank syariah banyak mengalami kolektifitas yang buruk. Namun peningkatan NPF suatu periode tidak langsung memberikan dampak penurunan keuntungan pada periode tersebut, sehingga bank tidak akan secara langsung mengurangi jumlah pembiayaan. FDR merupakan rasio untuk mengukur seberapa besar penyaluran pembiayaan bank yang diberikan kepada nasabah. Sehingga ketika $N P F$ naik, tidak akan mempengaruhi $F D R$ secara langsung. Hasil penelitian juga menunjukkan $F D R$ tidak memiliki pengaruh yang signifikan terhadap $R O A$, maka $N P F$ tidak dapat mempengaruhi $R O A$ melalui tingkat likuiditas yang diukur oleh $F D R$.

\section{FDR Sebagai Mediasi Pengaruh BOPO Terhadap ROA}

Hasil hipotesis kesepuluh $\mathrm{H}_{10}$ ditolak, artinya $F D R$ tidak dapat memediasi hubungan antara BOPO terhadap ROA pada bank umum Syariah. BOPO mampu mempengaruhi ROA secara langsung tanpa melalui $F D R$. BOPO merupakan rasio untuk mengetahui biaya operasional yang dikeluarkan dengan cara membandingkan beban operasional dengan pendapatan operasional. Ketika biaya operasional tinggi, bank akan melakukan strategi untuk menurunkan angka tersebut agar tidak semakin membengkak, yaitu dengan cara meningkatkan pendapatan. Pendapatan bank syariah dapat diperoleh dengan pengelolaan dana oleh bank sebagai mudharib, hak bagi hasil atas dana syirkah, pendapatan non operasional dan pendapatan operasional lainnya. FDR merupakan rasio untuk mengukur seberapa besar penyaluran pembiayaan yang diberikan bank. Pembiayaan juga merupakan salah satu sumber pendapatan bank. Namun, bank memiliki sumber pendapatan lain yang dapat meningkatkan pendapatan. Serta meninjau hasil uji $F D R$ tidak memiliki pengaruh yang signifikan terhadap $R O A$, sehingga besar kecilnya $F D R$ tidak mempengaruhi profitabilitas secara signifikan, maka BOPO tidak bisa mempengaruhi ROA melalui FDR.

\section{KESIMPULAN}

Ternyata variabel $C A R, N P F$, BOPO mempengaruhi $R O A$ secara negatif. Kemudian $C A R$ dan $N P F$ mempengaruhi FDR secara negatif, sedangkan BOPO mempengaruhi $F D R$ secara positif. $F D R$ mempengaruhi ROA secara positif namun $F D R$ tidak mampu menjadi variabel mediasi antara pengaruh $C A R, N P F$ dan BOPO terhadap ROA.

Bank syariah dalam meningkatkan laba bersih dapat meninjau rasio keuangan yang dimiliki. Prinsip kehati-hatian menjadi hal penting dalam penyaluran pembiayaan agar angka risiko pembiayaan $(N P F)$ turun, sehingga kualitas pembiayaan yang disalurkan dapat memiliki kualitas yang baik, serta diimbangi dengan menekan biaya operasional (BOPO) dapat menjadi suatu hal yang perlu dipertimbangkan guna meningkatkan keuntungan bank syariah. 
Hasil penelitian ini menemukan bahwa $F D R$ tidak mampu menjadi variabel yang menjembatani atau memediasi pengaruh $C A R, N P F$, dan BOPO terhadap $R O A$, sehingga penelitian selanjutnya bisa mencari variabel mediasi lainnya untuk menggantikan $F D R$. Selain itu, dapat juga menambah variabel lain yang melihat pengaruh terhadap $R O A$, karena hasil penelitian ini menemukan bahwa hanya variabel BOPO yang berpengaruh terhadap ROA. Penambahan jumlah sampel dan jumlah periode penelitian juga sangat disarankan untuk mendapatkan penemuan yang lebih baik kedepannya.

\section{DAFTAR PUSTAKA}

Achmad, Achmad. 2018. "Efek Capital Adequacy Ratio, Non Performin Financing dan Operational Effeciency Ratio Atas Return on Asset Pada Bank Umum Syariah Milik Negara". AT-TARADHI: Jurnal Studi Ekonomi 9 (2), 119-126. http://dx.doi.org/10.18592/at-taradhi.v9i2.2514.

Almunawwaroh, Medina, and Rina Marliana. 2018. "Pengaruh CAR, NPF dan FDR Terhadap Profitabilitas Bank Syariah di Indonesia". AMWALUNA: Jurnal Ekonomi Dan Keuangan Syari'ah 2 (1), 1-17. https://doi.org/10.29313/amwaluna.v2i1.3156.

Angraini, Dila. 2018. "Pengaruh Dana Pihak Ketiga, Non Performing Financing, Tingkat Bagi Hasil Dan Modal Sendiri Terhadap Profitabilitas Dengan Pembiayaan Bagi Hasil Sebagai Variabel Intervening Pada Perbankan Syariah". JABI: Jurnal Akuntansi Berkelanjutan Indonesia 1 (1), 122-146. http://dx.doi.org/10.32493/JABI.v1i1.y2018.p122-146.

Ariyanti, Indah, Patricia Dhiana Paramita, and Ari Pranaditya. 2017. "Pengaruh CAR, NPF, NIM, BOPO, dan DPK terhadap Profitabilitas dengan FDR sebagai Variabel Intervening (Studi Kasus Perbankan Umum Syariah Tahun 2011-2014)". Jurnal Ilmiah Mahasiswa S1 Akuntansi Universitas Pandanaran 3 (3), 1-20. http://jurnal.unpand.ac.id/index.php/AKS/article/view/802.

Armereo, Crystha. 2015. "Analisis Faktor-Faktor Yang Mempengaruhi Profitabilitas Bank Syariah Yang Terdaftar Di Bursa Efek Indonesia Indonesia". Jurnal Ilmiah Ekonomi Global Masa Kini 6 (2), 48-56. http://ejournal.uigm.ac.id/index.php/EGMK/article/view/65.

Astuti, Fitri. 2016. "Pengaruh Efisiensi Usaha, Risiko Keuangan Dan Kepercayaan Masyarakat Terhadap Kemampuan Penyaluran Pembiayaan Pada Bank Umum Syariah Di Indonesia Tahun 2011-2014”. Jurnal Ekonomi dan Keuangan Islam 2 (2), 10-20. http://dx.doi.org/10.20885/jeki.vol2.iss2.art2.

Ayu, Dea Putri and Anak Agung Gede Suarjaya. 2017. "Pengaruh Profitabilitas Terhadap Nilai Perusahaan Dengan Corporate Social Responsibility Sebagai Variabel Mediasi Pada Perusahaan Pertambangan". E-Jurnal $\begin{array}{llll}\text { Manajemen } & 6 & \text { (2), }\end{array}$ https://ojs.unud.ac.id/index.php/Manajemen/article/view/27825.

Edo, Delsy Setiawati Ratu, and Ni Luh Putu Wiagustini. 2014. "Pengaruh Dana Pihak Ketiga, Non Performing Loan, dan Capital Adequacy Ratio Terhadap Loan To Deposit Ratio dan Return on Assets Pada Sektor 
Perbankan Di Bursa Efek Indonesia". E-Jurnal Ekonomi Dan Bisnis 11 (3), 650-673. https://ojs.unud.ac.id/index.php/EEB/article/view/9777.

Ervina, Ervina, and Anindya Ardiansari. 2016. "Pengaruh Dana Pihak Ketiga, Non Performing Financing, Capitaladequacy Ratio dan Return on Asset, Terhadap Tingkat Likuiditas". Management Analysis Journal 5 (1), 7-16. https://journal.unnes.ac.id/sju/index.php/maj/article/view/5573.

Fadila, Dewi, and Yuliani Yuliani. 2015. "Peran ROA Sebagai Pemediasi CAR, NPL dan LDR Bank Pembangunan Daerah Di Indonesia." Jurnal Manajemen Dan Bisnis Sriwijaya $13 \quad$ (2), 217-228. https://ejournal.unsri.ac.id/index.php/jmbs/article/view/3350.

Fitria, Leny Nur. 2017. Analisis Pengaruh Rasio Keuangan Dan Dana Pihak Ketiga Terhadap Profitabilitas Melalui Financing To Deposit Ratio Sebagai Variabel Intervening Pada Perbankan Syariah (Studi Pada Bank Umum Syariah Periode 2011 - 2015). Skripsi Jurusan Perbankan Syariah Fakultas Ekonomi Universitas Islam Negeri (UIN) Maulana Malik Ibrahim. http://etheses.uin-malang.ac.id/5963/.

Haq, Nadia Arini. 2015. "Pengaruh Pembiayaan Dan Efisiensi Terhadap Profitabilitas Bank Umum Syariah”. Perbanas Review 1 (1), 107-124. http://jurnal.perbanas.id/index.php/JPR/article/view/12.

Harahap, Nurlaila, Hendra Harmain, Saparuddin Siregar, and Nova Maharani. 2017. "Pengaruh Islamic Social Reporting (ISR), Umur Perusahaan Dan Kepemilikan Saham Publik Terhadap Profitabilitas (ROA) Pada Perusahaan Yang Terdaftar Di Jakarta Islamic Index (JII) Tahun 20102014”. KITABAH: Jurnal Akuntansi dan Keuangan Syariah 1 (1), 69-91. http://jurnal.uinsu.ac.id/index.php/JAKS/article/view/817.

Harun, Usman. 2016. "Pengaruh Ratio-Ratio Keuangan CAR, LDR, NIM, BOPO, NPL Terhadap ROA". Jurnal Riset Bisnis Dan Manajemen 4 (1), 67-82. https://ejournal.unsrat.ac.id/index.php/jrbm/article/view/12352.

Hasbidin, Hasbidin, and Saparuddin Siregar. 2017. "Pengaruh NPF \& Biaya Opersional Per- Pendapatan Operasional Terhadap FDR Dan Dampaknya Pada Profitabilitas Perbankan Syariah." Al-Muamalat: Jurnal Hukum dan $\begin{array}{lllll}\text { Ekonomi } & \text { Syariah } & 2 & \text { 67-79. }\end{array}$ https://journal.iainlangsa.ac.id/index.php/muamalat/article/view/615.

Hermawan, Dwi, and Shoimatul Fitria. 2019. Pengaruh CAR, NPF, FDR, Dan BOPO Terhadap Tingkat Profitabilitas Dengan Variabel Kontrol Size. Skripsi Fakultas Ekonomika dan Bisnis Universitas Diponegoro Semarang. http://eprints.undip.ac.id/72792/.

Khoirunnisa, Hani Maulida, Rodhiyah Rodhiyah, and Saryadi Saryadi. 2016. "Pengaruh Capital Adequacy Ratio (CAR), Loan To Deposit Ratio (LDR) Dan BOPO Terhadap Profitabilitas (ROA dan ROE) Bank Persero Indonesia Yang Dipublikasikan Bank Indonesia Periode 2010-2015". JIAB: Jurnal Ilmu Administrasi Bisnis 5 (4), 264-271. https://ejournal3.undip.ac.id/index.php/jiab/article/view/13517.

Lemiyana, Lemiyana and Erdah Litriani. 2016. "Pengaruh NPF, FDR, BOPO Terhadap Return on Asset Pada Bank Umum Syariah". I-ECONOMICS: A Research Journal on Islamic Economics 2 (1), 31-49. http://jurnal.radenfatah.ac.id/index.php/ieconomics/article/view/1001. 
Lidyah, Rika, Oki Sania Riski, Dwithia Chan Yo Putri, Tri Agustina. 2019. "Pengujian Financing To Deposit Ratio (FDR) Sebagai Mediasi Antara Pembiayaan, Non Performing Financing (NPF) Dan Biaya Operasional Pendapatan Operasional (BOPO) terhadap Laba Pada Bank Umum Syariah Di Indonesia". I-Finance; a Research Journal on Islamic Finance 5 (2), 181-200. https://doi.org/10.19109//ifinace.v5i2.4914.

Ljube, Jolevski. 2017. "Non-Performing Loans and Profitability Indicators: The Case of the Republic of Macedenia". Journal of Contemporary Economic and Business Issues 4 (2), 5-20. https://www.ceeol.com/search/articledetail $? \mathrm{id}=581788$.

Maharani, Nadia Putri and Dony Abdul Chalid. 2013. "Analisis Pengaruh CAR yang Memperhitungkan Risiko Kredit dan Risiko Pasar terhadap Kinerja Bank di Indonesia”. Jurnal Manajemen dan Usahawan Indonesia 42 (2), 99-117. http://www.ijil.ui.ac.id/index.php/jmui/article/view/12303.

Munir, Misbahul. 2018. "Analisis Pengaruh CAR, NPF, FDR dan Inflasi Terhadap Profitabilitas Perbankan Syariah Di Indonesia." Ihtifaz: Journal of Islamic Economics, Finance, and Banking 1 (1), 89-98. https://doi.org/10.12928/ijiefb.v1i1.285.

OJK. 2021. Statistik Perbankan Syariah. Otoritas Jasa Keuangan. https://www.ojk.go.id/id/kanal/syariah/data-dan-statistik/statistikperbankan-syariah/default.aspx.

Pangestika, C. Zelin Winda Ayu and Musdholifah Musdholifah. 2018. "Pengaruh DPK, CAR, dan NPL Melalui LDR Sebagai Variabel Intervening Terhadap Profitabilitas Bank (Studi Pada Bank Terbesar Di Asia Tenggara Periode 2012-2016)". Jurnal Ilmu Manajemen (JIM) 6 (3): 136-147. https://jurnal.unesa.ac.id/index.php/jim/article/view/23866.

Pardede, Desi Natalia and Irene Rini Demi Pangestuti. 2016. "Analisis Pengaruh CAR, Dana Pihak Ketiga (DPK), NIM, dan LDR Terhadap Profitabilitas Perbankan". Diponegoro Journal of Management 5 (3), 1-13. https://ejournal3.undip.ac.id/index.php/djom/article/view/14176.

Pertiwi, Annisa Dharma and Sri Abidah Suryaninsih. 2018. "Pengaruh Pembiayaan Murabahah dan Financing To Deposit Ratio (FDR) Terhadap Profitabilitas Pada BNI Syariah" Jurnal Ekonomi dan Bisnis Islam 1 (3), 172-182. https://jurnal.unesa.ac.id/index.php/jei/article/view/25594.

Pinasti, Wildan Farhat and RR. Indah Mustikawati. 2018. "Pengaruh CAR, BOPO, NPL, NIM dan LDR terhadap Profitabilitas Bank Umum Periode 2011-2015". NOMINAL: Barometer Riset Akuntansi Dan Manajemen 7 (1). 126-142. https://doi.org/10.21831/nominal.v7i1.19365.

Putrianingsih, Dwi Indah, and Arief Yulianto. 2016. "Pengaruh Non Performing Loan (NPL) dan Capital Adequacy Ratio (CAR) Terhadap Profitabilitas (Studi Kasus Pada Perusahaan Perbankan Yang Terdaftar Di BEI Periode 2010-2013)". Management Analysis Journal 5 (2): 110-115. https://journal.unnes.ac.id/sju/index.php/maj/article/view/7622.

Rachmat, Afria Bagus and Euis Komariah. 2017. "Faktor-Faktor Yang Mempengaruhi Profitabilitas Pada Bank Umum Syariah Periode 20102015”. Jurnal Online Insan Akuntan 2 (1), 17-34. http://www.ejournalbinainsani.ac.id/index.php/JOIA/article/view/429. 
Riyadi, Slamet and Agung Yulianto. 2014. "Pengaruh Pembiayaan Bagi Hasil, Pembiayaan Jual Beli, Financing To Deposit Ratio (FDR) dan Non Performing Financing (NPF) Terhadap Profitabilitas Bank Umum Syariah Di Indonesia". Accounting Analysis Journal 3 (4), 466-474. https://journal.unnes.ac.id/sju/index.php/aaj/article/view/4208.

Sabtatianto, Reandy and Muhamad Yusuf. 2018. "Pengaruh BOPO, CAR, FDR dan ROA terhadap Tingkat Bagi Hasil Deposito Mudharabah pada Bank Umum Syariah di Indonesia". ULTIMA Accounting: Jurnal Ilmu Akuntansi 10 (2), 169-186. https://doi.org/10.31937/akuntansi.v10i2.978.

Sanjaya, Surya and Muhammad Fajri Rizky. 2018. "Analisis Profitabilitas Dalam Menilai Kinerja Keuangan Pada PT. Taspen (Persero) Medan”. KITABAH: Jurnal Akuntansi dan Keuangan 2 (2), 277-293. http://jurnal.uinsu.ac.id/index.php/JAKS/article/view/4152.

Sengkey, Jefri I. B., Sri Murni, and Joy Elly Tulung. 2018. "Analisis FaktorFaktor Yang Mempengaruhi Risiko Likuiditas Bank (Studi Kasus Pada Bank Umum Swasta Nasional yang Terdaftar di BEI Periode 2012-2015)”. Jurnal EMBA: Jurnal Riset Ekonomi, Manajemen, Bisnis Dan Akuntansi 6 (4), 3078-3087. https://ejournal.unsrat.ac.id/index.php/emba/article/view/21226.

Setiani, Nur, Edward Gagah, and Aziz Fathoni. 2018. "Analysis Of Effect Of CAR, NPF, FDR, and BOPO ON ROA (Study at Shariah Commercial Bank in Indonesia Period 2012-2016)". Journal of Manajemen 4 (4). http://jurnal.unpand.ac.id/index.php/MS/article/view/930.

Somantri, Yeni Fitriani and Wawan Sukmana. 2019. "Analysis Of Factors Affecting Financing To Deposit Ratio (FDR) at Islamic Commercial Banks In Indonesia”. BAKI: Berkala Akuntansi dan Keuangan Indonesia 4 (2), 61-71. http://dx.doi.org/10.20473/baki.v4i2.18404.

Suliyanto, Suliyanto. 2011. Ekonometrika Terapan Teori dan Aplikasi dengan SPSS. Yogyakarta: CV. Andi Offset.

Suwarno, Rima Cahya and Ahmad Mifdlol Muthohar. 2018. "Analisis Pengaruh NPF, FDR, BOPO, CAR, dan GCG Terhadap Kinerja Keuangan Bank Umum Syariah Di Indonesia Periode 2013-2017.” Bisnis: Jurnal Bisnis dan Manajemen Islam 6 (1), 94-117. http://dx.doi.org/10.21043/bisnis.v6i1.3699.

Triyani, Triyani. 2018. Pengaruh Fianancing to Deposit Ratio (FDR) Dan Office Channeling Terhadap Profitabilitas Unit Usaha Syariah 2015-2017. Skripsi Program Studi Perbankan Syariah Fakultas Ekonomi dan Bisnis Islam Universitas Islam Negeri (UIN) Raden Intan Lampung. http://repository.radenintan.ac.id/4019/.

Wardana, Ridhlo Ilham Putra and Endang Tri Widyarti. 2015. "Analisis Pengaruh CAR, FDR, NPF, BOPO, Dan Size Terhadap Profitabilitas Pada Bank Umum Syariah Di Indonesia (Studi Kasus Pada Bank Umum Syariah Di Indonesia Periode 2011-2014)". Diponegoro Journal of Management 4 (4), 1-11. https://ejournal3.undip.ac.id/index.php/djom/article/view/13338.

Wibisono, Muhammad Yusuf and Salamah Wahyuni. 2017. "Pengaruh CAR, NPF, BOPO, FDR Terhadap ROA Yang Dimediasi Oleh NOM". MANAGEMENT: Journal of Business and Management 17 (1), 41-62. https://jurnal.uns.ac.id/jbm/article/view/12304. 
Wijaya, Rendi. 2019. "Analisis Perkembangan Return On Assets (ROA) Dan Return On Equity (ROE) Untuk Mengukur Kinerja Keuangan". Jurnal Ilmu Manajemen 9 (1), 40-51. https://doi.org/10.32502/jimn.v9i1.2115.

Wityasari, Meryta and Irene Rini Demi Pangestuti. 2014. "Analisis Pengaruh Car, Dana Pihak Ketiga (DPK), NPL, dan LDR Terhadap Profitabilitas Perbankan Dengan LDR Sebagai Variabel Intervening". Diponegoro $\begin{array}{lllll}\text { Journal of } & \text { Management }\end{array}$ https://ejournal3.undip.ac.id/index.php/djom/article/view/12933.

Yusriani, Yusriani. 2018. "Pengaruh CAR, NPL, BOPO Dan LDR Terhadap Profitabilitas Pada Bank Umum Milik Negara Persero Di Bursa Efek Indonesia”. Jurnal Riset 4 (2), 1-17. https://economicsbosowa.unibos.id/index.php/eb/article/view/150. 